\title{
THORACOLUMBAR BURST FRACTURES, SHORT X LONG FIXATION: A META-ANALYSIS
}

\author{
FRATURAS TORACOLOMBARES DO TIPO EXPLOSÃO, FIXAÇÃO CURTA X LONGA: UMA METANÁLISE
}

FRACTURAS TORACOLUMBARES TIPO EXPLOSIÓN, FIJACIÓN CORTA X LARGA: UN META-ANÁLISIS

Carlos Alberto Assunção Filho', Filipe Cedro Simöes'1, Gabriel Oliveira Prado

1. Hospital Regional de Santo Antônio de Jesus, Andaiá, Santo Antônio de Jesus, BA, Brazil.

\begin{abstract}
The number of fixed segments in the surgical treatment of thoracolumbar burst fractures remains controversial. This study aims to compare the results of short and long fixation in thoracolumbar burst fractures through a meta-analysis of studies published recently. MEDLINE and Cochrane databases were used. Randomized controlled trials and non-randomized comparative studies (prospective and retrospective) were selected. Data were analyzed with the software Review Manager. There was no statistically significant difference in the Cobb angle of preoperative kyphosis. Long fixation showed lower average measurements postoperatively $(\mathrm{MD}=1.41 ; \mathrm{Cl}=0.73-2.08 ; \mathrm{p}<0.0001$ ) and in the last follow-up ( $\mathrm{MD}=3.98$; $\mathrm{Cl}=3.22-4.75 ; \mathrm{p}<0.00001)$. The short fixation showed the highest failure rates $(\mathrm{RD}=4.03 ; \mathrm{Cl}=1.33-12.16 ; \mathrm{p}=0.01)$ and increased loss of height of the vertebral body $(\mathrm{MD}=1.24 ; \mathrm{Cl}=0.49-1.98 ; \mathrm{p}=0.001)$, with shorter operative time $(\mathrm{MD}=-24.54 ; \mathrm{Cl}=-30.16--18.91 ; \mathrm{p}<0.00001)$. There was no significant difference in blood loss and clinical outcomes. The high rates of kyphosis correction loss with short fixation and the lower correction rate in the immediate postoperative period were validated. There was no significant difference in the blood loss rates because arthrodesis was performed in a short segment in the analyzed studies. The short fixation was performed in a shorter operative time, as expected. No study has shown superior clinical outcomes. The short fixation had worse rates of kyphosis correction in the immediate postoperative period, and increased loss of correction in long-term follow-up, making the long fixation an effective option in the management of this type of fracture.
\end{abstract}

Keywords: Thoracolumbar fractures; Short fixation; Long fixation; Meta-analysis; Posterior fixation.

\section{RESUMO}

A quantidade de segmentos fixados no tratamento cirúrgico das fraturas toracolombares tipo explosão continua controverso. Este estudo tem como objetivo comparar os resultados da fixação curta e da longa nas fraturas toracolombares do tipo explosão, por meio de uma metanálise dos estudos publicados recentemente. Foram utilizadas as bases de dados MEDLINE e COCHRANE. Foram selecionados estudos controlados randomizados e estudos comparativos não randomizados (prospectivos e retrospectivos). Os dados foram analisados com o software Review Manager. Não houve diferença estatisticamente significante na medida do ângulo de Cobb da cifose pré-operatória. A fixação longa apresentou medidas médias inferiores no pós-operatório $(M D=1,41 ; I C=0,73-2,08 ; p<0,0001)$ e no último seguimento $(M D=3,98 ; I C=3,22-4,75 ; p<0,00001)$. A fixação curta apresentou taxas de falha maiores $(R D=4,03 ; I C=1,33-12,16 ; p=0,01)$ e maior perda de altura do corpo vertebral $(M D=1,24 ; I C=0,49-1,98 ; p=0,001)$, com menor tempo operatório $(M D=-24,54 ; I C=$ $-30,16--18,91 ; p<0,00001)$. Não houve diferença estatisticamente significante na perda sanguínea e nos desfechos clínicos. As taxas elevadas de perda da correção da cifose na fixação curta e a menor taxa de correção no pós-operatório imediato foram validadas. Não houve diferença estatisticamente significante quanto às taxas de perda sanguínea, porque a artrodese foi realizada em um segmento curto nos trabalhos analisados. A fixação curta teve menor tempo operatório, como esperado. Nenhum estudo demonstrou superioridade dos resultados clínicos. A fixação curta apresentou taxas piores de correção da cifose no pós-operatório imediato e maior perda da correção no seguimento a longo prazo, fazendo da fixação longa uma opção efetiva no manejo deste tipo de fratura.

Descritores: Fratura toracolombar; Fixação curta; Fixação Longa; Metanálise, Fixação Posterior.

\section{RESUMEN}

El número de segmentos fijados en el tratamiento quirúrgico de las fracturas toracolumbares tipo explosión sigue siendo controvertido. Este estudio tiene como objetivo comparar los resultados de fijación corta y larga en las fracturas toracolumbares tipo explosión, a través de un meta-análisis de estudios publicados recientemente. Se utilizaron las bases de datos MEDLINE y COCHRANE. Se seleccionaron los ensayos controlados aleatorios y estudios comparativos no aleatorios (prospectivos y retrospectivos). Los datos fueron analizados con el software Review Manager. No hubo diferencia estadísticamente significativa en cuanto a la medida del ángulo de Cobb de la cifosis preoperatoria. Lar fijación larga mostró mediciones promedio más bajas en el postoperatorio $(M D=1,41, I C=0,73-2,08 ; p<0,0001)$ y en el último seguimiento (MD $=3,98, I C=3,22-4,75 ; p<0,00001)$. La fijación corta mostró las tasas de fracaso más altas $(R D=4,03, I C=1,33-12,16 ; p=0,01)$ y una pérdida mayor de la altura del cuerpo vertebral $(M D=1,24, I C=0,49-1,98 ; p=0,001)$, con un menor tiempo operatorio $(M D=-24,54 ;$ IC $=$ -30,16 - -18.91; $p<0,00001)$. No hubo diferencia significativa en la pérdida de sangre y los resultados clínicos. Se validaron las altas tasas de pérdida de corrección de la cifosis con la fijación corta y la menor tasa de corrección en el postoperatorio inmediato. No hubo diferencia significativa en las tasas de pérdida de sangre porque la artrodesis se realizó en un segmento corto en los estudios analizados. La fijación corta tuvo menor tiempo operatorio, como se esperaba. Ningún estudio ha demostrado resultados clínicos superiores. La fijación corta tuvo peores tasas de corrección de la cifosis en el postoperatorio inmediato y mayor pérdida de corrección en el seguimiento a largo plazo, por lo que la fijación larga es una opción efectiva en el manejo de este tipo de fracturas.

Descriptores: Fracturas toracolumbares; Fijación corta; Fijación larga; Meta-análisis; Fijación posterior. 


\section{INTRODUCTION}

Fractures of the vertebral spine are among the most feared lesions among patients and physicians, and their consequences can be devastating, ranging from mild pain and discomfort to serious paralysis and even death. ${ }^{1-4}$ Traffic accidents, falls, and sports accidents are the cause of the majority of these lesions. ${ }^{3-7}$ Associated injuries are common, such as rib fractures, bronchial rupture, pulmonary contusion or myocardial infarction, lesions of large vessels, cardiac tamponade and rupture of the diaphragm, in addition to fractures of the long bones. Some degree of neurological lesion is also common. ${ }^{8}$

The majority of these fractures occur in the thoracolumbar region, presumably because this is a junction of the thoracic spine, which is relatively immobile, and the lumbar spine, which is relatively mobile. ${ }^{9,10}$ This is also the most common site of unstable burst-type fractures, representing about $15 \%$ of vertebral spine injuries. ${ }^{7,11}$

In 1983, Denis ${ }^{12}$ proposed his "three column spine" theory, taking the sagittal plane as reference. The anterior column consists of the front half of the vertebral body and the anterior longitudinal ligament; the middle column includes the posterior half of the vertebral body and the posterior longitudinal ligament; and the posterior column includes the laminae, the facet joints, and the spinous processes with their corresponding ligaments. Thus, thoracolumbar burst fracture was defined as a lesion that involves the anterior and middle columns. A burst fracture is characterized by displacement or rotation of the posterior cortical of the vertebral body, compressing the spinal canal and altering the stability of vertebral spine. There is a greater concentration of load directly on the middle spine during the axial trauma, in the region comprised of the vertebral pedicles, which results in their pulling apart, and retropulsion of fragments from the posterior portion of the vertebral body toward the spinal canal. Denis considered thoracolumbar burst fractures to be unstable, as they involve at least two of his "columns". ${ }^{12}$

There are still controversies in relation to the stability criteria and the treatment options for burst fractures. ${ }^{11-14}$ Radiographic signs that include enlargement of the interspinous and interlaminar space, translation of the vertebral body greater than $2 \mathrm{~mm}$, kyphosis greater than 20 degrees, loss of height or compression of the spinal canal of more than $50 \%$, and fracture of the articular processes, are the most widely accepted parameters for the assessment of stability of the fracture. ${ }^{15,16}$

Although many studies have obtained good results with conservative treatment of thoracolumbar burst fractures, ${ }^{17-19}$ most authors agree that surgical treatment is necessary for unstable burst fractures. ${ }^{20,21}$ Surgical intervention can decompress neural elements, restore the height of the vertebral body, correct and prevent angular deformity, and promote stability of the vertebral spine, allowing early mobilization and promoting neurological improvement. ${ }^{22,23}$

The best option for surgical treatment of thoracolumbar fractures remains controversial, despite the greater knowledge of biomechanics and advances in surgical techniques. To date, no one method has proven to be the most suitable for the treatment of all types of lesions of the vertebral spine. ${ }^{24,25}$

Anterior and posterior approaches are associated with satisfactory results in the treatment of thoracolumbar injuries. However, they are not without complications, depending on various clinical and radiographic factors such as the patient's age, degree of impairment of the medullary canal, sagittal index, height of the vertebral body, degree of integrity of posterior elements and presence of neurological deficit. ${ }^{26}$ Posterior instrumentation is recommended by many authors, based on the excellent results achieved in terms of stability of the spine, anatomical alignment, postoperative neurological improvement, and low patient morbidity. ${ }^{27-29}$

Numerous pedicular fixation methods through a posterior approach have been described. ${ }^{24,25}$ One of the main differences between them is the number of fixed segments. ${ }^{30}$ Short fixations, with fewer stabilized and fused uninjured segments, can preserve the maximum thoracolumbar movement. However, unacceptable failure rates have been demonstrated in this kind of fixation, particularly in terms of the loss of correction of the kyphosis produced by the fracture. ${ }^{31}$

The aim of this study is to compare the results of surgical treatment of thoracolumbar burst fractures using the posterior approach with short versus long fixation, through a meta-analysis of recent published studies.

\section{MATERIALS AND METHODS}

\section{Search Strategies}

A literature search was performed using the MEDLINE databases and the center for clinical trials records of COCHRANE. We used the search terms "thoracolumbar fractures", "short-segment" and "long-segment', in different combinations. We also conducted a direct search of the studies included in the references to the articles found in the initial search. There was no restriction as to the language of the publication. The titles and abstracts of the works found in the electronic searches were evaluated. The full texts were then obtained for the articles selected.

\section{Selection Criteria and Quality Evaluation}

Finding only a small number of available controlled, randomized studies, we included also non-randomized comparative studies (prospective and retrospective). The inclusion criteria used were: 1) making a comparison between long and short fixation of fractures of the thoracolumbar junction; 2) evaluating adult patients with non-pathological thoracolumbar fractures; 3 ) Posterior approach with pedicular fixation as the sole technique chosen for the treatment; 4) complete articles in full. Articles with one of the following characteristics were excluded: 1) Biomechanical studies in cadavers, opinions and case reports; 2) repeated studies; 3) studies with the same (or part of) the patients from works already selected.

To evaluate the methodological quality of the studies included, we used different tools, according to the presence or not of randomization. For the non-randomized studies, the MINORS ${ }^{32}$ score was used, with a possible maximum of 24 points. For randomized prospective controlled studies, we used the Detsky Quality Scale ${ }^{33}$ which has a total score of 20 for possible assays and 21 for negative ones. Studies with values higher than $75 \%$ of the maximum score for the above scales were considered high quality.

\section{Data Extraction}

Information was collected on the study design, patients' profile, inclusion and exclusion criteria, interventions, outcomes and clinical and radiographic follow-up (duration and rate of loss).

\section{Analysis of the data and statistical methods}

The data were analyzed using the software Review Manager (RevMan) 5.1, with guidance from the Cochrane. We evaluated the heterogeneity of articles using the standard Chi square test, considering a statistical significance of $p>0.05$, and measurement of $\mathrm{I}^{2}$, in which values higher than $50 \%$ were considered substantial heterogeneity. In the existence of heterogeneity, we applied random effects to the data selected. Otherwise, we used the fixed effects model. Differences in risk and 95\% confidence interval $(\mathrm{Cl})$ were calculated for the dichotomous outcomes, and the median and 95\% Cl were calculated for the continuous outcomes.

\section{RESULTS}

The search strategy identified 476 articles, five of which met the pre-defined inclusion criteria pre-defined for the extraction of the data to be used in this meta-analysis. (Figure 1)

After compiling the contents obtained in these studies, we ob- 
tained a total of 189 patients, of which 91 underwent short fixation and 98 were treated with long fixation. The scores for the quality assessment ranged between $67 \%$ and $85 \%$ of the maximum scores for the scales used. The patient characteristics were similar in the majority of the groups evaluated. The mean age ranged from 32 to 44.8 years. A predominance of female patients was found only in the short fixation group of the study of Serín et al. ${ }^{31}$ and in the article of Guven et al. ${ }^{47}$ The first lumbar vertebra was the one most affected in all groups. The follow-up times ranged from 12 to 52 months. (Table 1)

\section{Radiographic Evaluation}

Local kyphosis, measured through the upper plateau of upper vertebra to the fractured level, and the lower plateau of the lower vertebra to the fractured level, as described by the Cobb method, was evaluated in all studies. There was no statistically significant difference in the evaluation of preoperative Cobb angle. In the postoperative evaluation the long fixation group presented smaller average measurements than those of the short fixation group $(M D=1.41$; $\mathrm{Cl}=0.73-2.08 ; \mathrm{p}<0.0001)$. In the analysis of Cobb angle of the last segment, the short fixation group obtained larger measurements $(\mathrm{MD}=3.98 ; \mathrm{Cl}=3.22-4.75 ; \mathrm{p}<0.00001)$. (Tables 2, 3 and 4)

Altay et al., ${ }^{34}$ Serín et al. ${ }^{31}$ And Tezeren et al. ${ }^{48}$ defined fixation failure as loss of kyphosis as correction of 10 degrees or more. According to this criterion, the short fixation group presented higher failure rates higher than the long fixation group $(R D=4.03$; $\mathrm{Cl}=1.33$ - 12.16; $\mathrm{p}=0.01$ ). (Table 5)

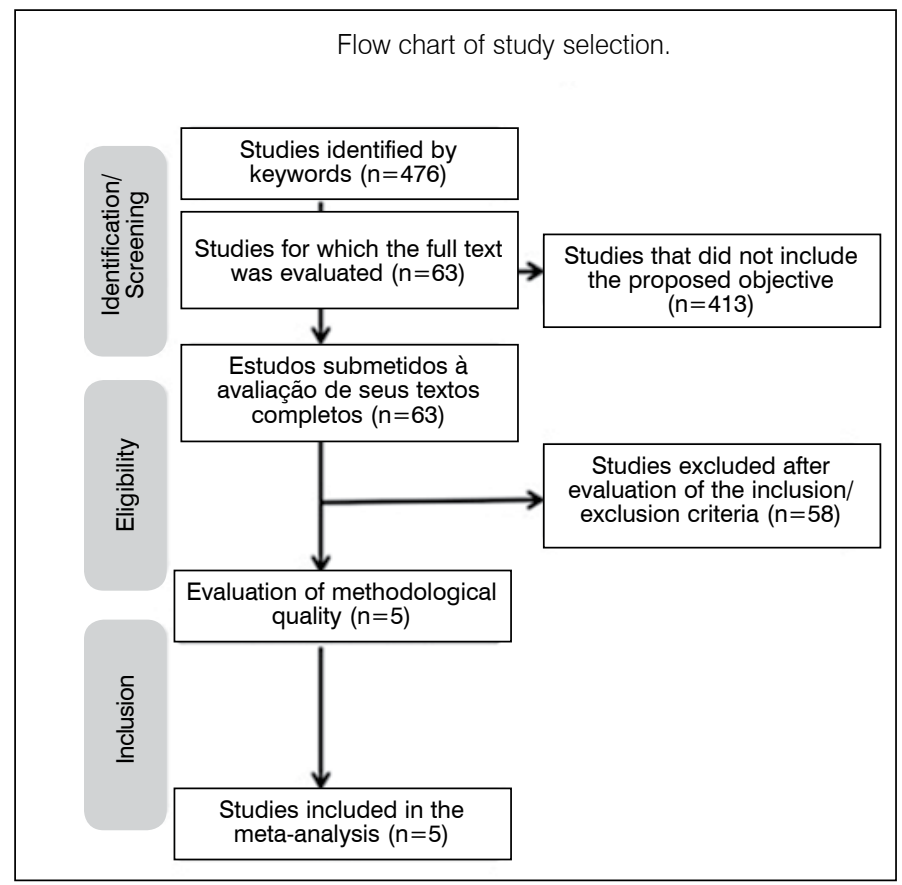

Figure 1. Flow chart of study selection.

Table 1. Characteristics of the studies included.

\begin{tabular}{|c|c|c|c|c|c|c|c|c|c|c|}
\hline Study & Year & Nationality & Study Design & $\begin{array}{l}\text { Quality } \\
\text { Scale }\end{array}$ & Groups & \begin{tabular}{|c|} 
No of \\
Patients
\end{tabular} & Mean age (years) & $\begin{array}{l}\text { Sex } \\
M-F\end{array}$ & $\begin{array}{c}\text { Fracture } \\
\text { level }\end{array}$ & Follow-up time (months) \\
\hline \multirow{2}{*}{$\begin{array}{c}\text { Sapkas } \\
\text { et al }\end{array}$} & \multirow{2}{*}{2010} & \multirow{2}{*}{ Greece } & \multirow{2}{*}{$\begin{array}{c}\text { Prospective } \\
\text { Non- } \\
\text { Randomized }\end{array}$} & \multirow{2}{*}{$18 / 24(75 \%)$} & $\begin{array}{c}\text { Short } \\
\text { fixation }\end{array}$ & 20 & $33(13-52)$ & $(12 / 08)$ & \multirow{2}{*}{$\mathrm{L} 1=23$} & $34(25-70)$ \\
\hline & & & & & $\begin{array}{c}\text { Long } \\
\text { fixation }\end{array}$ & 30 & $35(17-55)$ & $(20 / 10)$ & & $36(24-72)$ \\
\hline \multirow{2}{*}{$\begin{array}{l}\text { Serín } \\
\text { et al }\end{array}$} & \multirow[b]{2}{*}{2004} & \multirow[b]{2}{*}{ Turkey } & \multirow{2}{*}{$\begin{array}{c}\text { Prospective } \\
\text { Non- } \\
\text { Randomized }\end{array}$} & \multirow[b]{2}{*}{ 19/24 (79\%) } & $\begin{array}{c}\text { Short } \\
\text { fixation }\end{array}$ & 12 & $32.4(+/-9.5)$ & $(4 / 8)$ & $\mathrm{L} 1=6$ & 12 \\
\hline & & & & & $\begin{array}{c}\text { Long } \\
\text { fixation }\end{array}$ & 10 & $35.5(+/-13.6)$ & $(7 / 3)$ & $\mathrm{L} 1=4$ & 12 \\
\hline \multirow[b]{2}{*}{ Altay et al } & \multirow[b]{2}{*}{2007} & \multirow[b]{2}{*}{ Turkey } & \multirow[b]{2}{*}{ Retrospective } & \multirow[b]{2}{*}{ 16/24 (67\%) } & $\begin{array}{c}\text { Short } \\
\text { fixation }\end{array}$ & 32 & $42.6(+/-14.9)$ & $(19 / 13)$ & $L 1=13$ & $36(18-58)$ \\
\hline & & & & & $\begin{array}{l}\text { Long } \\
\text { fixation }\end{array}$ & 31 & $44.8(+/-14.9)$ & $(18 / 13)$ & $\mathrm{L} 1=16$ & $33(18-58)$ \\
\hline \multirow{2}{*}{$\begin{array}{c}\text { Terezen } \\
\text { et al }\end{array}$} & \multirow[b]{2}{*}{2005} & \multirow[b]{2}{*}{ Turkey } & \multirow{2}{*}{$\begin{array}{l}\text { Prospective } \\
\text { randomized }\end{array}$} & \multirow[b]{2}{*}{$15 / 20(75 \%)$} & $\begin{array}{c}\text { Short } \\
\text { fixation }\end{array}$ & 9 & $32(+/-13)$ & $(7 / 2)$ & $\mathrm{L} 1=7$ & $29+/-5(23-38)$ \\
\hline & & & & & $\begin{array}{l}\text { Long } \\
\text { fixation }\end{array}$ & 9 & $34(+/-11)$ & $(8 / 1)$ & $\mathrm{L} 1=7$ & $29+/-4(24-40)$ \\
\hline \multirow{2}{*}{$\begin{array}{l}\text { Guven } \\
\text { et al }\end{array}$} & \multirow{2}{*}{2009} & \multirow{2}{*}{ Turkey } & \multirow{2}{*}{$\begin{array}{l}\text { Prospective } \\
\text { randomized }\end{array}$} & \multirow{2}{*}{$17 / 20(85 \%)$} & $\begin{array}{c}\text { Short } \\
\text { fixation }\end{array}$ & 18 & $37.4(+/-3.7)$ & \multirow{2}{*}{$13: 23$} & $\mathrm{~L} 1=10$ & $48.1+/-13.8$ \\
\hline & & & & & $\begin{array}{c}\text { Long } \\
\text { fixation }\end{array}$ & 18 & $40.8(+/-7.2)$ & & $L 1=7$ & $52.1+/-3.8$ \\
\hline
\end{tabular}

Table 02. Forest plot showing the preoperative Cobb angle.

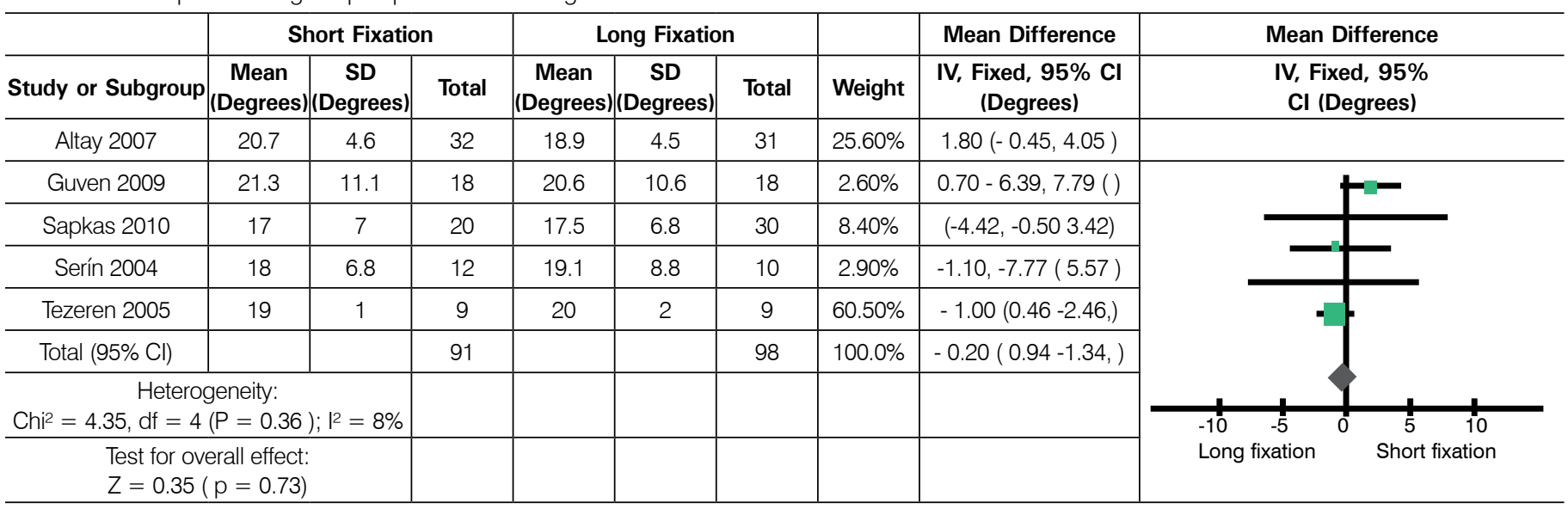


Guven and col., ${ }^{47}$ Serín et al., ${ }^{31}$ Tezeren et al. ${ }^{48}$ assessed the loss of height of the vertebral body. The group also presented poor short fixations in the analysis of posteroperative results $(M D=1.24$; $\mathrm{Cl}=0.49-1.98 ; \mathrm{p}=0.001)$ and in the last segment $(\mathrm{MD}=6.53$; $\mathrm{Cl}=5.82-7.24 ; \mathrm{p}<0.00001$ ). (Tables 6, 7 and 8)

\section{Surgical time}

Four clinical trials evaluated the surgical time (Guven et al., ${ }^{47}$ Serín et al., ${ }^{31}$ Tezeren et al., ${ }^{48}$ Sapkas et al. ${ }^{49}$ The short fixation group obtained lower mean surgical times, compared with the long fixation group, with statistically significant difference (MD = $-24.54 ; \mathrm{Cl}=-30.16-18.91 ; \mathrm{p}<0.00001)$. (Table 9)

\section{Blood loss}

Guven et al., ${ }^{47}$ Sapkas et al., ${ }^{49}$ Tezeren et al. ${ }^{48}$ assessed blood loss, and found no statistically significant difference between the groups. (Table 10)

Table 03. Forest plot showing the postoperative Cobb angle.

\begin{tabular}{|c|c|c|c|c|c|c|c|c|c|c|}
\hline \multirow[b]{2}{*}{$\begin{array}{l}\text { Study or } \\
\text { Subgroup }\end{array}$} & \multicolumn{3}{|c|}{ Short Fixation } & \multicolumn{3}{|c|}{ Long Fixation } & \multirow[b]{2}{*}{ Weight } & \multirow{2}{*}{$\begin{array}{c}\text { Mean Difference } \\
\text { IV, Fixed, 95\% CI } \\
\text { (Degrees) }\end{array}$} & \multirow{2}{*}{\multicolumn{2}{|c|}{$\begin{array}{c}\text { Mean Difference } \\
\text { IV, Fixed, } 95 \% \mathrm{CI} \text { (Degrees) }\end{array}$}} \\
\hline & \multicolumn{2}{|c|}{\begin{tabular}{|c|c|} 
Mean & SD \\
(Degrees) & (Degrees)
\end{tabular}} & \multirow{2}{*}{$\begin{array}{c}\text { Total } \\
32 \\
\end{array}$} & \multirow{2}{*}{\begin{tabular}{|c|}
$\begin{array}{c}\text { Mean } \\
\text { (Degrees) }\end{array}$ \\
5 \\
\end{tabular}} & \multirow{2}{*}{\begin{tabular}{|c|}
$\begin{array}{c}\text { SD } \\
\text { (Degrees) }\end{array}$ \\
3.6 \\
\end{tabular}} & \multirow{2}{*}{$\begin{array}{c}\text { Total } \\
31\end{array}$} & & & & \\
\hline Altay 2007 & 7.8 & 5.3 & & & & & $9.20 \%$ & $2.80(0.57,5.03)$ & & \\
\hline Guven 2009 & 8.5 & 2.2 & 18 & 6.5 & 2.8 & 18 & $16.90 \%$ & $2.00(0.35,3.65)$ & & \\
\hline Sapkas 2010 & 5 & 3.5 & 20 & 3 & 2 & 30 & $16.00 \%$ & $2.00(0.31,3.69)$ & & \\
\hline Total (95\% Cl) & & & 91 & & & 98 & $100.0 \%$ & $1.41(0.73,2.08)$ & & \\
\hline $\begin{array}{r}\text { Heter } \\
\text { Chi² }^{5.46,} \text { df }=4 \\
\end{array}$ & $\begin{array}{l}\text { geneity : } \\
P=0.24) ; ।\end{array}$ & ${ }^{2}=27 \%$ & & & & & & & $\begin{array}{l}-10 \quad-5 \\
\text { Long fixation }\end{array}$ & $\begin{array}{cc}5 & 10 \\
\text { Short fixation }\end{array}$ \\
\hline $\begin{array}{l}\text { Test for } 0 \\
Z=4.07\end{array}$ & $\begin{array}{l}\text { verall effect: } \\
P<0.0001\end{array}$ & & & & & & & & & \\
\hline
\end{tabular}

Table 04. Forest plot showing the follow-up Cobb angle.

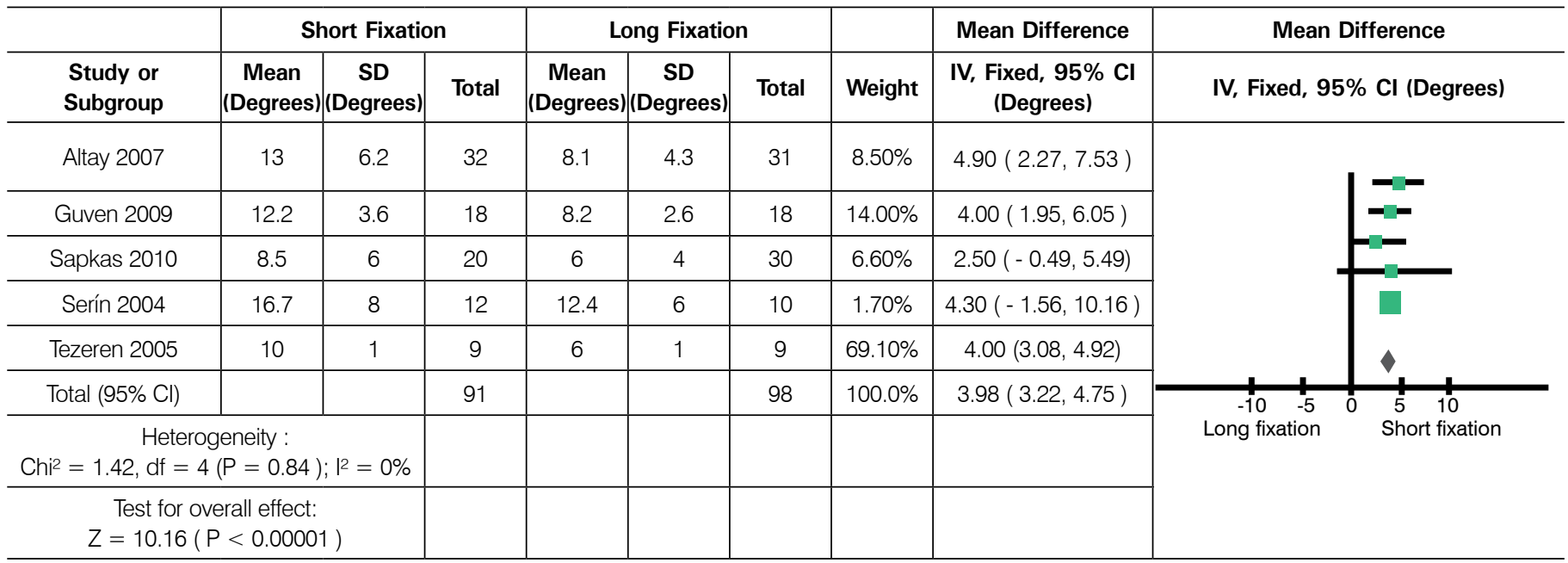

Table 05. Forest plot showing fixation failure.

\begin{tabular}{|c|c|c|c|c|c|c|c|}
\hline & \multicolumn{2}{|c|}{ Short Fixation } & \multicolumn{2}{|c|}{ Long Fixation } & Weight & $\begin{array}{c}\text { Risk ratio } \\
\mathrm{M}-\mathrm{H}, \text { Random, } 95 \% \mathrm{Cl}\end{array}$ & $\frac{\text { Risk ratio }}{\mathrm{M}-\mathrm{H}, \text { Random, } 95 \% \mathrm{Cl}}$ \\
\hline Altay 2007 & 6 & 32 & 2 & 31 & $52.70 \%$ & $2.91(0.63,13.32)$ & \multirow{6}{*}{$\begin{array}{cccc}0.005 & 0.1 & 1 & 10 \\
\text { Long fixation } & & \text { Short fixation }\end{array}$} \\
\hline Serín 2004 & 5 & 12 & 1 & 10 & $31.30 \%$ & $4.17(0.58,30.06)$ & \\
\hline Tezeren 2005 & 5 & 9 & 0 & 9 & $16.00 \%$ & $11.00(0.70,173.66)$ & \\
\hline Total events & 16 & & 3 & & & & \\
\hline \multicolumn{4}{|c|}{$\begin{array}{c}\text { Heterogeneity : } \\
\text { Tau }^{2}=0.00, \text { Chi }^{2}=0.71, \text { df }=2(P=0.70) ;\left.\right|^{2}=0 \%\end{array}$} & & & & \\
\hline $\begin{array}{l}\text { Test for overall } \\
Z=2.47(P=\end{array}$ & ffect: & & & & & & \\
\hline
\end{tabular}


Table 06. Forest plot showing the preoperative height of the vertebral body.

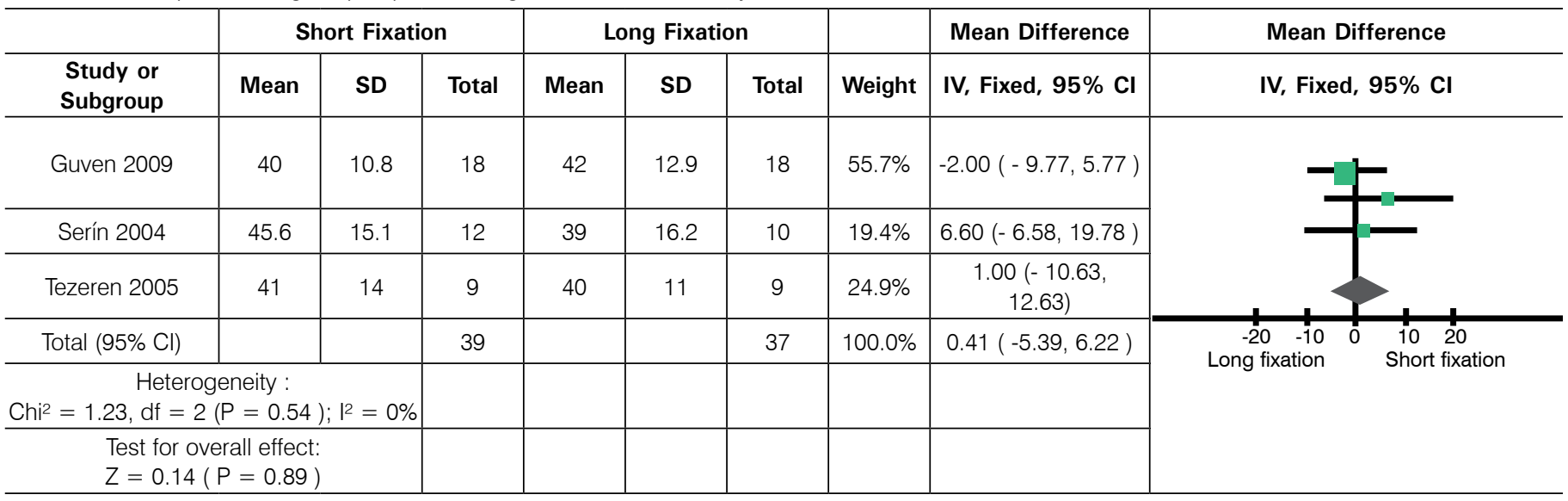

Table 07. Forest plot showing the postoperative height of the vertebral body

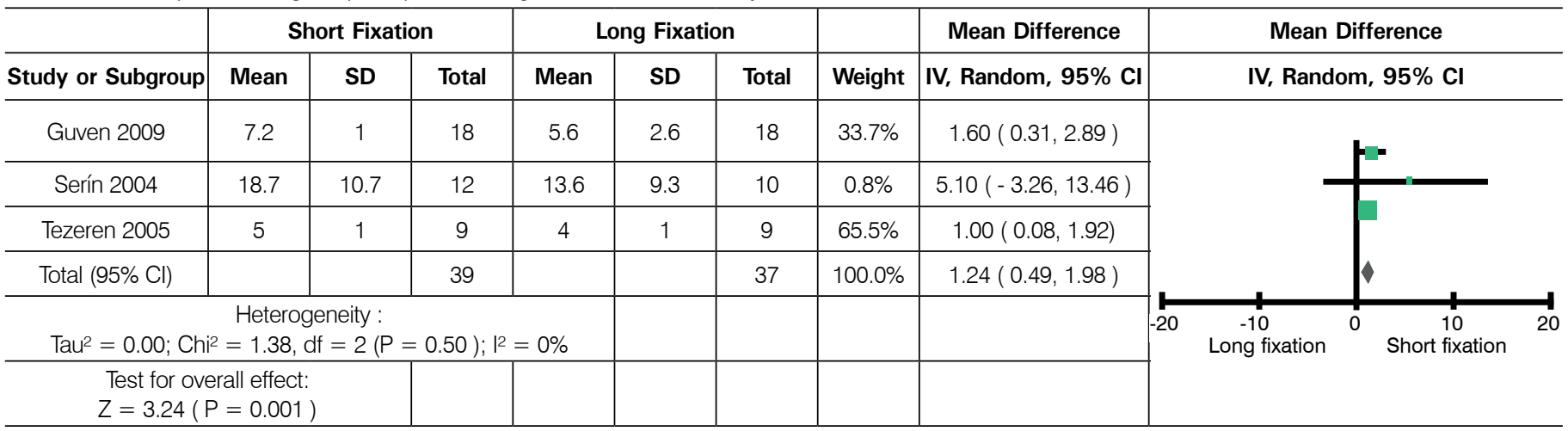

Table 08. Forest plot showing the follow-up height of the vertebral body.

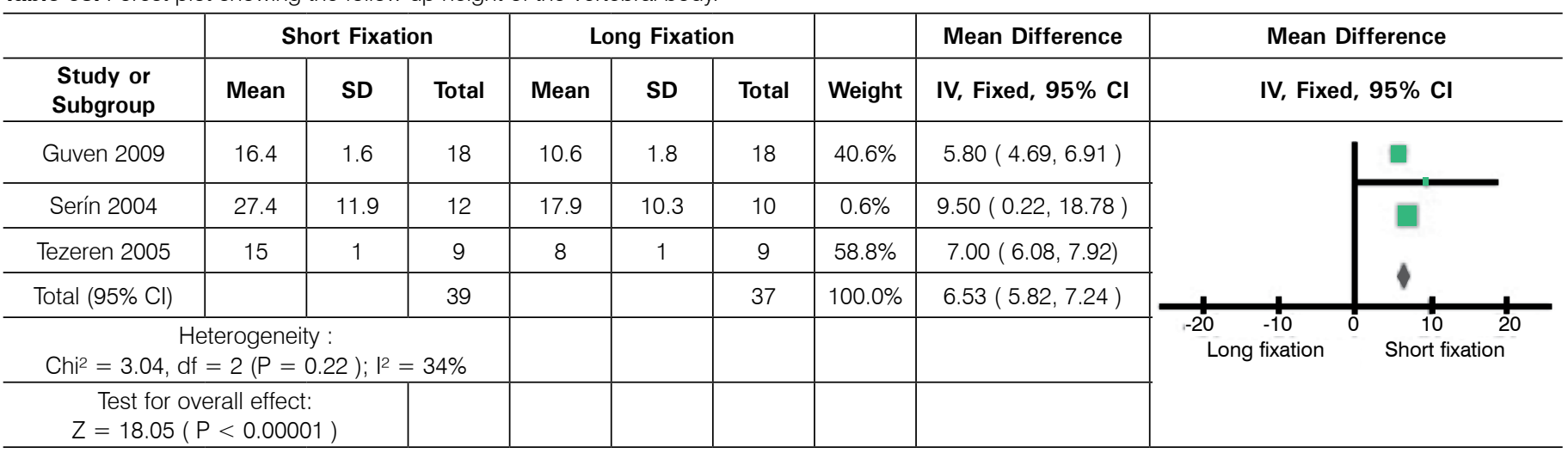

\section{Clinical Evaluation}

Different instruments were used for to assess the clinical results (pain scale of Denis, Likert questionnaire, Low Back Outcome Score - LBOS), making statistical analysis more difficult. No study found statistically significant difference in clinical outcomes.

\section{DISCUSSION}

The treatment of thoracolumbar fractures remains controversial, ${ }^{34}$ despite the increase of open-surgery following the introduction of surgical instrumentation. ${ }^{35}$ The Harrington system, initially developed to treat scoliosis, in 1958, was later adapted for spinal fractures, ${ }^{36}$ and was gradually replaced by pedicle screws, as described by Boucher ${ }^{37}$ in 1959. In 1963, Roy-Camille et al. ${ }^{38}$ also described the association of plates with the pedicle screw. In 1985, Dick et al. ${ }^{39}$ described a new instrumentation technique, known as "internal fixation", and proposed, through it, a short fixation method for the treatment of spinal fractures.

Initially, short instrumentation was considered a method of instrumentation that would bring the advantages of sparing arthrodesis levels in the surgical treatment of spinal fractures. ${ }^{39-41}$ However, subsequent work showed high rates of failure of this technique. ${ }^{42-45}$ A greater kyphotic deformity would result in higher anterior vertebral stress transmitted to the pedicle screws, which would explain these failures. ${ }^{9,16,28}$ Long fixation distributes the stress between the screws, and also promotes greater correction of the kyphotic deformity, which decreases the demand for instrumentation material and, consequently, the chance of failure.

Yu et al. ${ }^{46}$ and McLain et al. ${ }^{43}$ showed high rates of loss of kyphosis correction during follow-up of patients submitted to short posterior fixation. These results were validated in our study, in which the analysis of the studied data enabled us to confirm sta- 
Table 09. Forest plot showing the surgical time.

\begin{tabular}{|c|c|c|c|c|c|c|c|c|c|}
\hline \multirow[b]{2}{*}{ Study or Subgroup } & \multicolumn{3}{|c|}{ Short Fixation } & \multicolumn{3}{|c|}{ Long Fixation } & \multirow[b]{2}{*}{ Weight } & \multirow{2}{*}{\begin{tabular}{|c|} 
Mean \\
Difference \\
IV, Fixed, 95\% \\
Cl (minutes) \\
\end{tabular}} & \multirow{2}{*}{$\begin{array}{c}\text { Mean Difference } \\
\text { IV, Fixed, 95\% } \\
\text { CI (minutes) }\end{array}$} \\
\hline & $\begin{array}{c}\text { Mean } \\
\text { (minutes) }\end{array}$ & $\begin{array}{c}\text { SD } \\
\text { (minutes) }\end{array}$ & Total & $\begin{array}{c}\text { Mean } \\
\text { (minutes) }\end{array}$ & $\begin{array}{c}\text { SD } \\
\text { (minutes) }\end{array}$ & Total & & & \\
\hline Guven 2009 & 132 & 15 & 18 & 138 & 10 & 18 & $45,60 \%$ & $\begin{array}{c}-6.00 \\
(-14.33,2.33) \\
\end{array}$ & \multirow{7}{*}{ 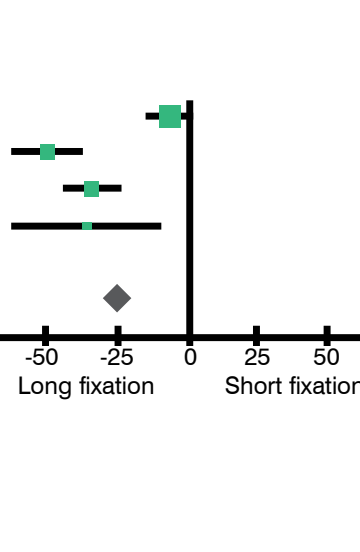 } \\
\hline Sapkas 2010 & 170 & 20 & 20 & 220 & 25 & 30 & $20,20 \%$ & $\begin{array}{c}-50.00 \\
(-62.52,-37.48) \\
\end{array}$ & \\
\hline Serín 2004 & 105 & 10.7 & 12 & 139 & 13.4 & 10 & $30,00 \%$ & $\begin{array}{c}-34.00 \\
(-44.28,-23.72)\end{array}$ & \\
\hline Tezeren 2005 & 152 & 27 & 9 & 188 & 32 & 9 & $4,20 \%$ & $\begin{array}{c}-36.00 \\
(-63.35,-8.65) \\
\end{array}$ & \\
\hline Total $(95 \%$ Cl) & & & 59 & & & 67 & $100.0 \%$ & $\begin{array}{c}-24.54 \\
(-30.16,-18.91) \\
\end{array}$ & \\
\hline \multicolumn{9}{|c|}{$\begin{array}{c}\text { Heterogeneity : } \\
\mathrm{Chi}^{2}=38.84, \mathrm{df}=3(\mathrm{P}<0.00001) ; \mathrm{l}^{2}=92 \%\end{array}$} & \\
\hline \multicolumn{3}{|c|}{$\begin{array}{c}\text { Test for overall effect: } \\
Z=8.55(P<0.00001)\end{array}$} & & & & & & & \\
\hline
\end{tabular}

Table 10. Forest plot showing blood loss.

\begin{tabular}{|c|c|c|c|c|c|c|c|c|c|}
\hline \multirow[b]{2}{*}{ Study or Subgroup } & \multicolumn{3}{|c|}{ Short Fixation } & \multicolumn{3}{|c|}{ Long Fixation } & \multirow[b]{2}{*}{ Weight } & \multirow{2}{*}{\begin{tabular}{|c|} 
Mean Difference \\
$\begin{array}{c}\text { IV, Random, 95\% } \\
\mathrm{Cl}(\mathrm{mL})\end{array}$
\end{tabular}} & \multirow{2}{*}{$\begin{array}{c}\text { Mean Difference } \\
\text { IV, Random, 95\% } \\
\text { CI (mL) }\end{array}$} \\
\hline & $\begin{array}{c}\text { Mean } \\
(\mathrm{mL})\end{array}$ & SD (mL) & Total & $\begin{array}{c}\text { Mean } \\
(\mathrm{mL})\end{array}$ & $\mathrm{SD}(\mathrm{mL})$ & Total & & & \\
\hline Guven 2009 & 430 & 60 & 18 & 425 & 55 & 18 & $44.50 \%$ & $\begin{array}{c}5.00 \\
(-32.60,42.60) \\
\end{array}$ & \multirow{6}{*}{$\begin{array}{ccc}-200 & 0 & 100200 \\
\text { Short fixation } & \text { Short fixation }\end{array}$} \\
\hline Sapkas 2010 & 1.050 & 260 & 20 & 1.200 & 350 & 30 & $23.80 \%$ & $\begin{array}{c}-150.00 \\
(-319.32,19.32) \\
\end{array}$ & \\
\hline Tezeren 2005 & 411 & 111 & 9 & 550 & 145 & 9 & $31.60 \%$ & $\begin{array}{c}-139.00 \\
(-258.30,-19.70)\end{array}$ & \\
\hline Total $(95 \%$ Cl) & & & 47 & & & 57 & $100.0 \%$ & $\begin{array}{c}-77.51 \\
(-195.81,40.80)\end{array}$ & \\
\hline \multicolumn{4}{|c|}{$\begin{array}{c}\text { Heterogeneity : } \\
\text { Tau }^{2}=7814.04 ; \text { Chi }^{2}=7.68, \mathrm{df}=2(\mathrm{P}=0.02) ; \mathrm{I}^{2}=74 \%\end{array}$} & & & & & & \\
\hline \multicolumn{3}{|c|}{$\begin{array}{l}\text { Test for overall effect: } \\
Z=1.28(P=0.20)\end{array}$} & & & & & & & \\
\hline
\end{tabular}

tistical significance not only for loss of kyphosis correction, with $\mathrm{p}<0.00001$, but also a lower rate of correction rate measured immediately after surgery $(p<0.0001)$.

Alanay et al. ${ }^{42}$ defined fixation failure as loss of kyphosis correction of more than $10^{\circ}$. That study obtained fixation failure rates of $40 \%$ and $50 \%$ in each group. In our meta-analysis, we were able to use this criterion in three of the studies, with the statistical analysis showing a high failure rate in short fixation during the patient follow-up, with statistical significance (relative risk of 4.03 [1.33 - 12.16] and $p<0.01$ ).

Although it is a surgical technique that requires lower intervention and less instrumentation, the short fixation group did not obtain a statistically significant difference in terms of blood loss. This can be explained by the fact that the arthrodesis was performed on one segment only in all the studies analyzed, regardless of whether the fixation was long or short.

As expected, because it uses less instrumentation, short fixation was superior in the analysis of surgery times. It resulted in shorter surgery times, with a mean difference of 24.54 minutes [30.16 - 18.91] $(p<0.00001)$.

Despite the better radiographic results of long fixation, no study demonstrated superiority any of the fixation types compared, in terms of clinical and functional results. The different parameters used to analyze the clinical results in the works evaluated did not allow for comparison of these data.

\section{CONCLUSION}

This meta-analysis demonstrates that the surgical treatment of unstable thoracolumbar burst fractures using a short fixation presented poorer rates of kyphosis correction immediately after surgery, and greater loss of this correction in the long-term follow-up of patients, compared to long fixation. These radiographic findings make long fixation an effective option in the management of thoracolumbar burst fractures type. Despite the higher rate of failures with short fixation, it has shorter surgical times. The clinical outcome could not be evaluated in this meta-analysis, although no statistically significant differences were shown in the data for the studies evaluated.

All authors declare no potential conflict of interest concerning this article. 


\section{REFERENCES}

1. Cassar-Pullicino VN. Spinal injury: optimising the imaging options. Eur J Radiol. 2002:42(2):85-91.

2. Jelly LM, Evans DR, Easty MJ, Coats TJ, Chan O. Radiography versus spiral CT in the evaluation of cervicothoracic junction injuries in polytrauma patients who have undergone intubation. Radiographics. 2000;20(Spec No):S251-9.

3. Bensch FV, Kiuru MJ, Koivikko MP, Koskinen SK. Spine fractures in falling accidents: analysis of multidetector CT findings. Eur Radiol. 2004;14(4):618-24.

4. Starr JK, Hanley EN Jr. Junctional burst fractures. Spine (Phila Pa 1976). 1992;17(5):551-7.

5. Floyd T. Alpine skiing, snowboarding, and spinal trauma. Arch Orthop Trauma Surg. 2001 Sep;121(8):433-6.

6. Kiuru MJ, Koivikko MP, Koskinen SK. Serious horse-riding accidents: imaging findings and evaluation with multi-slice CT. Emerg Radiol. 2002:9(4):213-8.

7. Wilcox RK, Boerger TO, Allen DJ, Barton DC, Limb D, Dickson RA, et al. A dynamic study of thoracolumbar burst fractures. J Bone Joint Surg Am. 2003;85(11):2184-9.

8. Wood KB, Li W, Lebl DR, Ploumis A. Management of thoracolumbar spine fractures. Spine J. 2014:14(1):145-64.

9. Müller U, Berlemann U, Sledge J, Schwarzenbach O. Treatment of thoracolumbar burst fractures without neurologic deficit by indirect reduction and posterior instrumentation: bisegmental stabilization with monosegmental fusion. Eur Spine J. 1999:8(4):284-9.

10. Magerl F, Aebi M, Gertzbein SD, Harms J, Nazarian S. A comprehensive classification of thoracic and lumbar injuries. Eur Spine J. 1994;3(4):184-201.

11. Bohlman $\mathrm{HH}$. Treatment of fractures and dislocations of the thoracic and lumbar spine. $J$ Bone Joint Surg Am. 1985:67(1):165-9.

12. Denis F. Spinal instability as defined by the three-column spine concept in acute spinal trauma. Clin Orthop Relat Res. 1984;(189):65-76.

13. Meves R, Avanzi O. Correlation between neurological deficit and spinal canal compromise in 198 patients with thoracolumbar and lumbar fractures. Spine (Phila Pa 1976). 2005;30(7):787-91.

14. Atlas SW, Regenbogen $V$, Rogers LF, Kim KS. The radiographic characterization of burst fractures of the spine. AJR Am J Roentgenol. 1986;147(3):575-82.

15. Petersilge CA, Emery SE. Thoracolumbar burst fracture: evaluating stability. Semin Ultrasound CT MR. 1996;17(2):105-13.

16. ChoWS, Chung CK, Jahng TA, Kim HJ. Post-laminectomy kyphosis in patients with cervical ossification of the posterior longitudinal ligament : does it cause neurological deterioration? J Korean Neurosurg Soc. 2008;43(6):259-64.

17. Dai LY, Jiang LS, Jiang SD. Conservative treatment of thoracolumbar burst fractures: a long-term follow-up results with special reference to the load sharing classification. Spine (Phila Pa 1976). 2008;33(23):2536-44.

18. Post RB, van der Sluis CK, Leferink VJ, ten Duis HJ. Long-term functional outcome after type A3 spinal fractures: operative versus non-operative treatment. Acta Orthop Belg. 2009;75(3):389-95

19. Thomas KC, Bailey CS, Dvorak MF, Kwon B, Fisher C. Comparison of operative and nonoperative treatment for thoracolumbar burst fractures in patients without neurological deficit: a systematic review. J Neurosurg Spine. 2006;4(5):351-8.

20. Heary RF, Salas S, Bono CM, Kumar S. Complication avoidance: thoracolumbar and lumbar burst fractures. Neurosurg Clin N Am. 2006;17(3):377-88.

21. Kim HS, Lee SY, Nanda A, Kim JY, Park JO, Moon SH, et al. Comparison of surgical outcomes in thoracolumbar fractures operated with posterior constructs having varying fixation length with selective anterior fusion. Yonsei Med J. 2009;50(4):546-54.

22. Akalm S, Ki M, Benli IT, Citak M, Mumcu EF, Tüzüner M. Results of the AO spinal internal fixator in the surgical treatment of thoracolumbar burst fractures. Eur Spine J. 1994;3(2):102-6.

23. Mayer $H$, Schaaf $D$, Kudernatsch $M$. Use of internal fixator in injuries of the thoracic and lumbar spine. Chirurg. 1992:63(11):944-9.

24. Dekutoski MB, Conlan ES, Salciccioli GG. Spinal mobility and deformity after Harrington rod stabilization and limited arthrodesis of thoracolumbar fractures. J Bone Joint Surg Am. 1993:75(2):168-76.

25. Katonis PG, Kontakis GM, Loupasis GA, Aligizakis AC, Christoforakis JI, Velivassakis EG. Treatment of unstable thoracolumbar and lumbar spine injuries using Cotrel-Dubousset instrumentation. Spine (Phila Pa 1976). 1999:24(22):2352-7.

26. Dai $L Y$, Jiang SD, Wang $X Y$, Jiang $L S$. A review of the management of thoracolumbar burst fractures. Surg Neurol. 2007;67(3):221-31.

27. Cresswell TR, Marshall PD, Smith RB. Mechanical stability of the AO internal spinal fixa- tion system compared with that of the Hartshill rectangle and sublaminar wiring in the management of unstable burst fractures of the thoracic and lumbar spine. Spine (Phila Pa 1976). 1998;23(1):111-5

28. Parker JW, Lane JR, Karaikovic EE, Gaines RW. Successful short-segment instrumentation and fusion for thoracolumbar spine fractures: a consecutive 41/2-year series. Spine (Phila Pa 1976). 2000;25(9):1157-70.

29. Sjostrom L, Karlstrom G, Pech P, Rauschning W. Indirect spinal canal decompression in burst fractures treated with pedicle screw instrumentation. Spine (Phila Pa 1976). 1996:21(1):113-23.

30. Cheng LM, Wang JJ, Zeng ZL, Zhu R, Yu Y, Li C, et al. Pedicle screw fixation for traumatic fractures of the thoracic and lumbar spine. Cochrane Database Syst Rev. 2013:5:CD009073.

31. Serin E, Karakurt L, Yilmaz E, Belhan O, Varol T. Effects of two-levels, four-levels, and four-levels plus offset-hook posterior fixation techniques on protecting the surgical correction of unstable thoracolumbar vertebral fractures: a clinical study. Eur J Orthop Surg Traumatol. 2004:14(1):1-6.

32. Slim K, Nini E, Forestier D, Kwiatkowski F, Panis Y, Chipponi J. Methodological index for non-randomized studies (minors): development and validation of a new instrument. ANZ J Surg. 2003;73(9):712-6.

33. Detsky AS, Naylor CD, O'Rourke K, McGeer AJ, L'Abbé KA. Incorporating variations in the quality of individual randomized trials into meta-analysis. J Clin Epidemiol. 1992;45(3):25565.

34. Altay M, Ozkurt B, Aktekin CN, Ozturk AM, Dogan O, Tabak AY. Treatment of unstable thoracolumbar junction burst fractures with short- or long-segment posterior fixation in magerl type a fractures. Eur Spine J. 2007;16(8):1145-55.

35. Lindsey RW, DickW. The fixateur interne in the reduction and stabilization of thoracolumbar spine fractures in patients with neurologic deficit. Spine (Phila Pa 1976). 1991;16(Suppl 3):S140-5.

36. Dickson JH, Harrington PR, Erwin WD. Results of reduction and stabilization of the severely fractured thoracic and lumbar spine. J Bone Joint Surg Am. 1978;60(6):799-805.

37. Boucher HH. A method of spinal fusion. The Journal of Bone and Joint Surgery 1959;41B(2):248-59

38. Roy-Camille R, Saillant G, Mazel C. Internal fixation of the lumbar spine with pedicle screw plating. Clin Orthop Relat Res. 1986;(203):7-17.

39. Dick W, Kluger P, Magerl F, Woersdörfer O, Zäch G. A new device for internal fixation of thoracolumbar and lumbar spine fractures: the 'fixateur interne'. Paraplegia. $1985 ; 23(4): 225-32$

40. Sanderson PL, Fraser RD, Hall DJ, Cain CM, Osti OL, Potter GR. Short segment fixation of thoracolumbar burst fractures without fusion. Eur Spine J. 1999;8(6):495-500.

41. Rommens PM, Weyns F, Van Calenbergh F, Goffin J, Broos PL. Mechanical performance of the Dick internal fixator: a clinical study of 75 patients. Eur Spine J. 1995;4(2):104-9.

42. Alanay A, Acaroglu E, Yazici M, Oznur A, Surat A. Short-segment pedicle instrumentation of thoracolumbar burst fractures: does transpedicular intracorporeal grafting prevent early failure? Spine (Phila Pa 1976). 2001;26(2):213-7.

43. McLain RF, Sparling E, Benson DR. Early failure of short-segment pedicle instrumentation for thoracolumbar fractures. A preliminary report. J Bone Joint Surg Am. 1993:75(2):162-7.

44. Kramer DL, Rodgers WB, Mansfield FL. Transpedicular instrumentation and short-segment fusion of thoracolumbar fractures: a prospective study using a single instrumentation system. J Orthop Trauma. 1995;9(6):499-506.

45. Carl AL, Tromanhauser SG, Roger DJ. Pedicle screw instrumentation for thoracolumbar burst fractures and fracture-dislocations. Spine (Phila Pa 1976). 1992;17(Suppl 8):S317-24.

46. Yu SW, Fang KF, Tseng IC, Chiu YL, Chen YJ, Chen WJ. Surgical outcomes of short-segment fixation for thoracolumbar fracture dislocation. Chang Gung Med J. 2002;25(4):253-9

47. Guven O, Kocaoglu B, Bezer M, Aydin N, Nalbantoglu U. The Use of Screw at the Fracture Level in the Treatment of Thoracolumbar Burst Fractures. J Spinal Disord Tech. 2009;22(6):417-21

48. Tezeren G, Kuru I. Posterior Fixation of Thoracolumbar Burst Fracture : short-segment pe dicle fixation versus long-segment instrumentation. J Spinal Disord Tech. 2005;18(6):485-8

49. Sapkas G, Kateros K, Papadakis SA, Brilakis E, Macheras G, Katonis P. Treatment of Unstable Thoracolumbar Burst Fractures by Indirect Reduction and Posterior Stabilization: shot-segment versus long-segment stabilization. The Open Orthopaedics Journal. $2010 ; 4: 7-13$ 